\title{
Physical Characteristics and Nutritional Contents of Peanut Flour and Black Oncom (Fermented Peanut Meal) Flour
}

\author{
A. Rohimah ${ }^{1}$, B. Setiawan ${ }^{2 *}$, E. Palupi ${ }^{2}$, A. Sulaeman ${ }^{2}$,and E. \\ Handharyani ${ }^{3}$
}

\begin{abstract}
${ }^{1}$ Doctoral Program in Nutrition Sciences, Graduate School, Department of Community Nutrition, Faculty of Human Ecology, IPB University, Bogor, West Java, 16680, Indonesia

${ }^{2}$ Department of Community Nutrition, Faculty of Human Ecology, IPB University, Bogor, West Java, 16680, Indonesia

${ }^{3}$ Department of Veterinary Clinic Reproduction and Pathology, Faculty of Veterinary Medicine, IPB University, Bogor, West Java, 16680, Indonesia
\end{abstract}

Corresponding author: bsetiawan@apps.ipb.ac.id

\begin{abstract}
The solid state fermentation (SSF) process technology can improve the physical characteristics and nutritional contents of legume flour. The aim of this study was to determine the physical characteristics and nutritional contents of peanut flour and black oncom (fermented peanut meal) flour. This research was conducted at the Food Experiment Laboratory and Food Nutrition Analysis Laboratory, Nutrition Science Study Program, Faculty of Human Ecology, Institut Pertanian Bogor (IPB) University. The research design was a completely randomized design using independent $\mathrm{t}$-test analysis. The results showed that black oncom flour had lower bulk density $(0.74$ $\mathrm{g} / \mathrm{ml})$ and higher water absorption $(1.79 \mathrm{~g} / \mathrm{g})$ compared to peanut flour. The content of protein (43.9\%) and ash $(2.65 \%)$ of black oncom flour was higher than peanut flour. The physical characteristics (bulk density and water absorption) and nutritional contents (protein and ash) have significantly different $(\mathrm{p}<0.05)$.Therefore, black oncom flour has potentially good to be incorporated into food products.
\end{abstract}

Keywords:Black oncom flour, nutritional contents, peanut flour, physical characteristics, solid state fermentation

\section{INTRODUCTION}

Peanut (Arachis hypogeae L.) has an important role in the daily consumption of Indonesian people, because it contains protein, fat, unsaturated fatty acids, carbohydrate, fiber, minerals, vitamins, amino acids and phytonutrient components [1]. The average consumption of peanuts and its processed products was $2.4 \mathrm{~g}$, with the proportion of the population consuming peanuts and its processed products at $11.2 \%$. Peanuts are commonly used for vegetable oil production. The production generates byproducts in the form of peanut meal which contains several functional components such as protein, fiber, polyphenols, antioxidants, vitamins and minerals that could be added as functional ingredients to food [2];[3];[4]. Peanut meal commonly used by the people of West Java as a substrate in a solid state fermentation (SSF) technology that produces traditional food of black oncom[5]. SSF can improve nutritional and nutraceutical characteristics due to the presence of fungi which plays an important role in synthesizing enzymes that hydrolyze several substrates and contribute to the development of texture, taste and aroma of products [6] and improve nutritional contents[7]; [8].

Black oncom contains nutrients such as protein, fat, carbohydrate, ash[9];[10],dietary fiber, unsaturated fatty acids, amino acids [11], functional components such as antioxidants, phenolics[12], and has higher protein digestibility [10]than peanuts due to the fermentation process by Rhizopus oligosporus fungi. Peanuts and black oncom can be processed into food products which are cookies and biscuits that require peanuts in the form of flour[13]. Therefore, it is necessary to process peanut into flour so that it is practical in its use. On the other hand, the use of black oncom is also limited because of its short shelf life, so efforts are needed to process black oncom flour so that it can 
be used as food ingredients for biscuits [14];[13], cookies [15] and brownies [16].

Black oncom flour may has good characteristics compared to peanut flour in terms of physical and nutritional characteristics due to the fermentation process in its production. During the fermentation, the protein can be hydrolyzed into simpler molecules and its anti-nutritional substances experience decrease so that it will have good characteristics[17]. Therefore, this explanation consider was pointed to evaluatedifferences in physical and nutritional characteristics between peanut flour and black oncom (fermented peanut meal) flour.

\section{MATERIALS AND METHOD}

\subsection{Design, Time and Location of Research}

Research design that was applicated was a completely randomized design (RAL). The treatment of this study was unfermented and fermented process namely, peanut flour as unfermented process and black oncom (fermented peanut meal) flour as fermented process.Both of peanut flour and black oncom flour were analyzed duplicately. This research was conducted at the Food Experiment Laboratory and Food and Nutrition Analysis Laboratory, Study Program of Nutrition Sciences, Faculty of Human Ecology, Institut Pertanian Bogor (IPB) University.

\subsection{Data Analysis}

The data were processed using Microsoft excel for windows 2010 and analyzed using SPSS 16 with independent sample t-test analysis. The data was interpreted as significantly different, if pvalue $<0.05$.

\subsection{Research procedures}

\subsubsection{Research material preparation}

The main ingredients in the form of peanuts and peanut meal were taken from peanut and peanut oildistributors. The materials for nutrition analysis were selenium mix, $4 \%$ boric acid, methyl red indicator, $0.1 \mathrm{~N} \mathrm{HCl}$, concentrated $\mathrm{H}_{2} \mathrm{SO}_{4}, 40 \% \mathrm{NaOH}, \quad 0.5 \mathrm{~N} \mathrm{NaOH}$, Hexane, whatman 42 filter paper, aluminum foil, sodium phosphate buffer $\mathrm{pH} \mathrm{4,6,7,8}$ and 10 , distilled water.

\subsubsection{The Production Process of Black Oncom}

The production process of black oncom began with soaking peanut meal for 15-16 hours. After that, the peanut meal was drained and steamed for 60 minutes. When it started to cool, the peanut meal was sprinkled with yeasts while stirring, then molded and fermented for 48 hours. The whole production process of black oncom is described in Figure

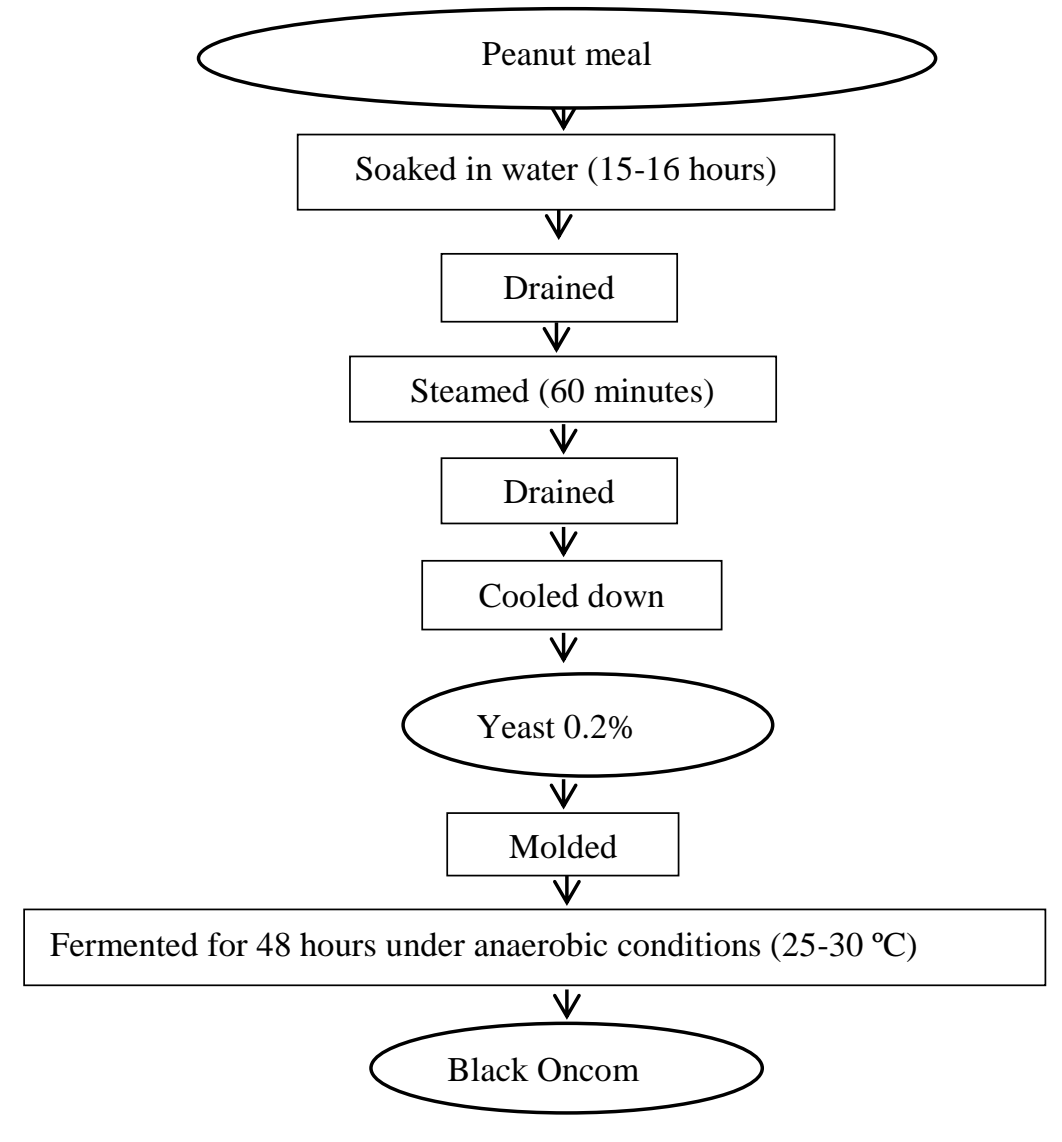

Figure1 The production process of black oncom [5] 


\subsubsection{The Production Process of Peanut and Black OncomFlours}

The production process of peanut flour was different from the black oncom flour. The roasting process of peanut was selected as a method to make peanut flour, because this process was better in removing the unpleasant odor caused by peanuts according to the research procedure [18].

The production process of black oncom flour was performed by modifying the flouring process carried out by [15];[16]. The process began

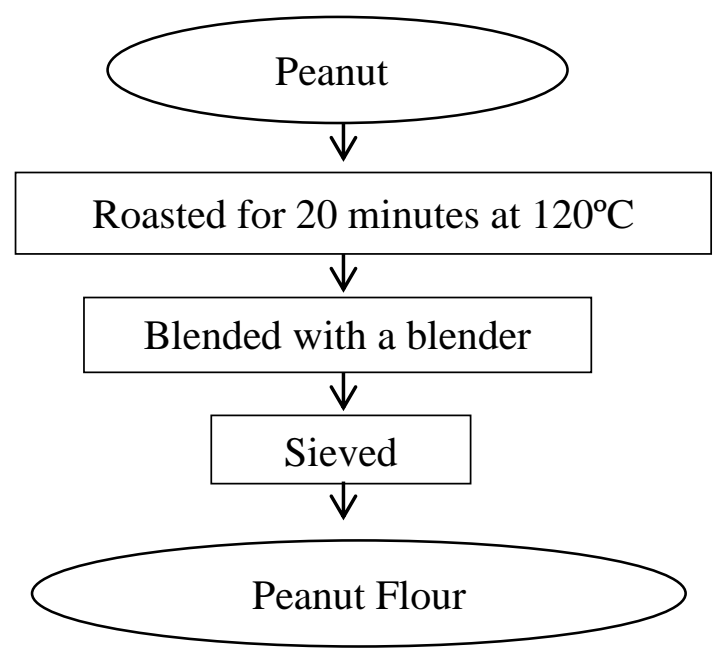

Figure2 Production Process of peanut flour by steaming the black oncom that was thinly sliced for 15 minutes then roasted at $60-70{ }^{\circ} \mathrm{C}$ for 7 hours, followed by grinding and sieving until it became flour. Meanwhile, the production process of peanut flour was according to [18], which was performed by roasting the peanut at a temperature of $120{ }^{\circ} \mathrm{C}$ for 20 minutes, then it was cooled and continued with grinding and sieving to produce the flour. The production processes are shown in Figure 2 (peanut flour) and Figure 3 (black oncom flour).

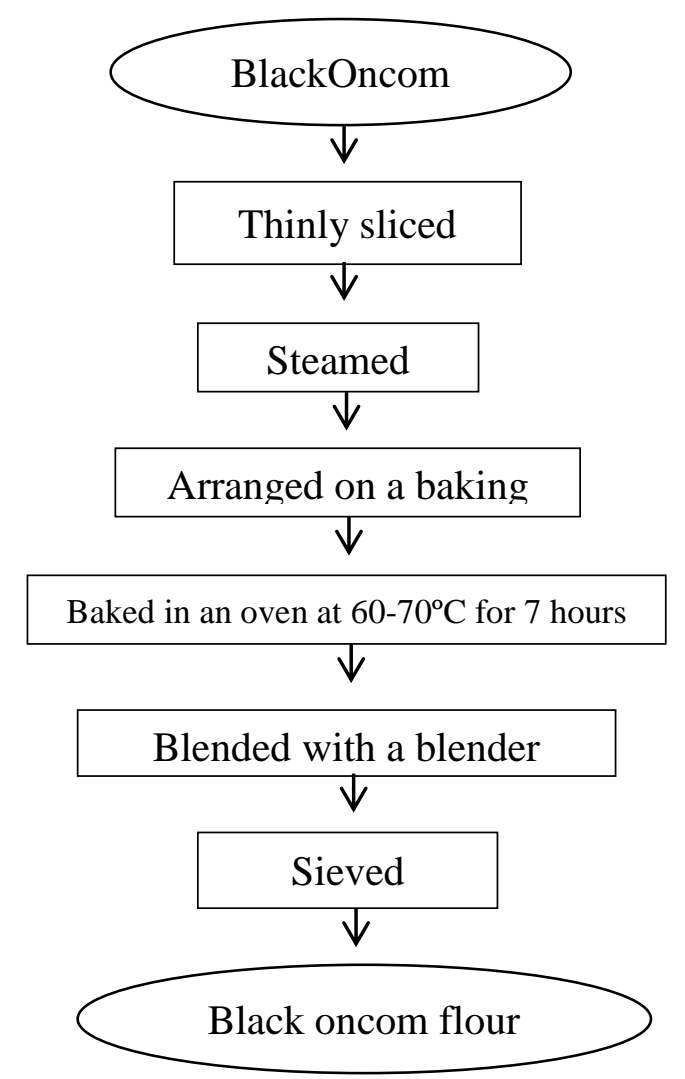

Figure3 The production process of black oncom flour

water ties per gram of flour[19]. Bulk density analysis of the flours was carried out by weighing the flour sample, and it was added into a $10 \mathrm{ml}$ graduated cylinder. The next step was tapped ituntil a constant volume was obtained and there were no cavities. Bulk density was expressed as a sample mass $(\mathrm{g})$ per sample volume (ml) [12].

\subsection{Proximate Analysis}

\subsubsection{Water content}

Two gram sample was weighed on an aluminum cup that was dried in an oven for 1 hour and its weight was recorded. The cup containing the sample was dried for 5 hours at $105^{\circ} \mathrm{C}$ in an oven. The cup containing the sample was put in a 
desiccator. When it was started to cool, the cup containing the sample was weighed [20].

\subsubsection{Ash Content}

Porcelain cup was dried in the furnace for 1 hour at $550{ }^{\circ} \mathrm{C}$. The cup was cooled first in a desiccator. After cooled, the porcelain cup was weighed to determine its weight. $3 \mathrm{~g}$ of sample was added in the cup and weighed with a known weight. The process of heating was then carried out in a heating bath until the white ash disappeared. The cups and samples were then ashed in the furnace for 5 hours at $550{ }^{\circ} \mathrm{C}$. The cups and samples were then weighed after being cooled in a desiccator [20].

\subsubsection{Protein Content}

$0.5 \mathrm{~g}$ sample was put into a digest flask then one spatula of selenium mix was added. A total of $6 \mathrm{~mL}$ of concentrated $\mathrm{H}_{2} \mathrm{SO}_{4}$ was added to the tube containing the sample. The sample was then destructed for 1 hour in a digestor at $420^{\circ} \mathrm{C}$. Samples were added with $30 \mathrm{~mL}$ of distilled water after the white smoke was disappeared. The sample was then distilled in a kjel digester connected to $40 \% \mathrm{NaOH}$ for 3 minutes and added with Erlenmeyer containing $4 \%$ boric acid and $\mathrm{mm}$ : $\mathrm{mb}$ indicator. The color of the solution in Erlenmeyer was changed from purple to green after it was distilled. The next step was titrated the solution using $0.1 \mathrm{~N} \mathrm{HCl}$ until the color was changed from green to purple[20].

\subsubsection{Fat Content}

A fat boiling flask was heated in an oven for 1 hour at $105^{\circ} \mathrm{C}$ then the flask was weighed after it was cooled in a desiccator. A sample of 0.5 gram was weighed and put into a lead paper. The lead paper containing the sample was folded and put into a Soxhlet tube and was submerged in hexane. The top of Soxhlet tube was covered with cotton. The tube was put into the Soxhlet extractor, and the lever was in the rinsing position. The fat boiling flask was filled with hexane as much as 30 $\mathrm{mL}$, then was mounted on a rack and put into a Soxhlet extractor. The Soxhlet extractor performed the fat extraction process that was started by a 20 minutes boiling process, 40 minutes and 10 minutes rinsing process, and recovery process was for 2 minutes. The extractor's temperature was waited until decreased (not hot) then the fat boiling flask was taken and dried in an oven for 1 hour at $105^{\circ} \mathrm{C}$. The Soxhlet tube was released one by one then the remaining hexane from the extraction process was taken by opening the extractor taps and was collected in a $5 \mathrm{~mL}$ beaker glass. The dried fat boiling flask was weighed after being cooled in a desiccator [20].

\section{RESULTS AND DISCUSSION}

\subsection{Physical Characteristics of Black Oncom Flour}

Physical characteristics measured from the flour were bulk density, water absorption and $\mathrm{pH}$ value. The measurementresults were presented in Table 1. Data in Table 1 showed that black oncom flour had a lower bulk density compared to peanut flour. This caused the particle size of peanut flour to be smaller and more dense in occupying a space. Black oncom flour had a smaller space density than peanut flour because it had a lower density.

Table 1 Physical characteristics of peanut flour and black oncomflour

\begin{tabular}{|l|c|c|}
\hline Parameter & Peanut flour & Black oncom flour \\
\hline Bulk density $(\mathrm{g} / \mathrm{mL})$ & $1.00 \pm 0.03^{\mathrm{b}}$ & $0.74 \pm 0.02^{\mathrm{a}}$ \\
\hline Water absorption $(\mathrm{g} / \mathrm{g})$ & $1.06 \pm 0.02^{\mathrm{a}}$ & $1.79 \pm 0.01^{\mathrm{b}}$ \\
\hline $\mathrm{pH}$ & $6.54 \pm 0.07^{\mathrm{a}}$ & $6.56 \pm 0.25^{\mathrm{a}}$ \\
\hline
\end{tabular}

${ }^{a, b}$ means that in one line with different superscript lowercase letters, it was significantly different $(\mathrm{p}<0.05)$

The bulk density describes the material mass that occupies a unit of volume, where the greater the bulk density, the more concise the material occupies the same volume with greater mass [21]. The low bulk density value of black oncom flour was because the raw material of peanut had undergone a defatting process before it was processed into black oncom. The defatting process contributes to the thickness of flour [21]. This process made black oncom flour was more numerous in occupying the space. The bulk density value of black oncom flour in this study is close to the results of the study[12], which was $0.86 \mathrm{~g} / \mathrm{ml}$. This value is also close to the research results by
[22] for the beans flour, which the oil were released, that was $0.89 \mathrm{~g} / \mathrm{ml}$.

The water absorption characteristics of black oncom flour achieved a higher absorption capacity than peanut flour. This is likely to occur due to the opening of the site or place of water binding from the side chains of protein groups, so that the absorption capacity of black oncom flour is higher than that of unfermented peanuts. The water absorption capacity of black oncom flour was relatively high because it approached the water absorption of rapeseed meal protein isolatewhich was $2.00 \mathrm{~g} / \mathrm{g}$ solid [23], industrial almond flour which was $1.86 \mathrm{~g} / \mathrm{g}$ solid[19] and soy protein isolate [24]. 

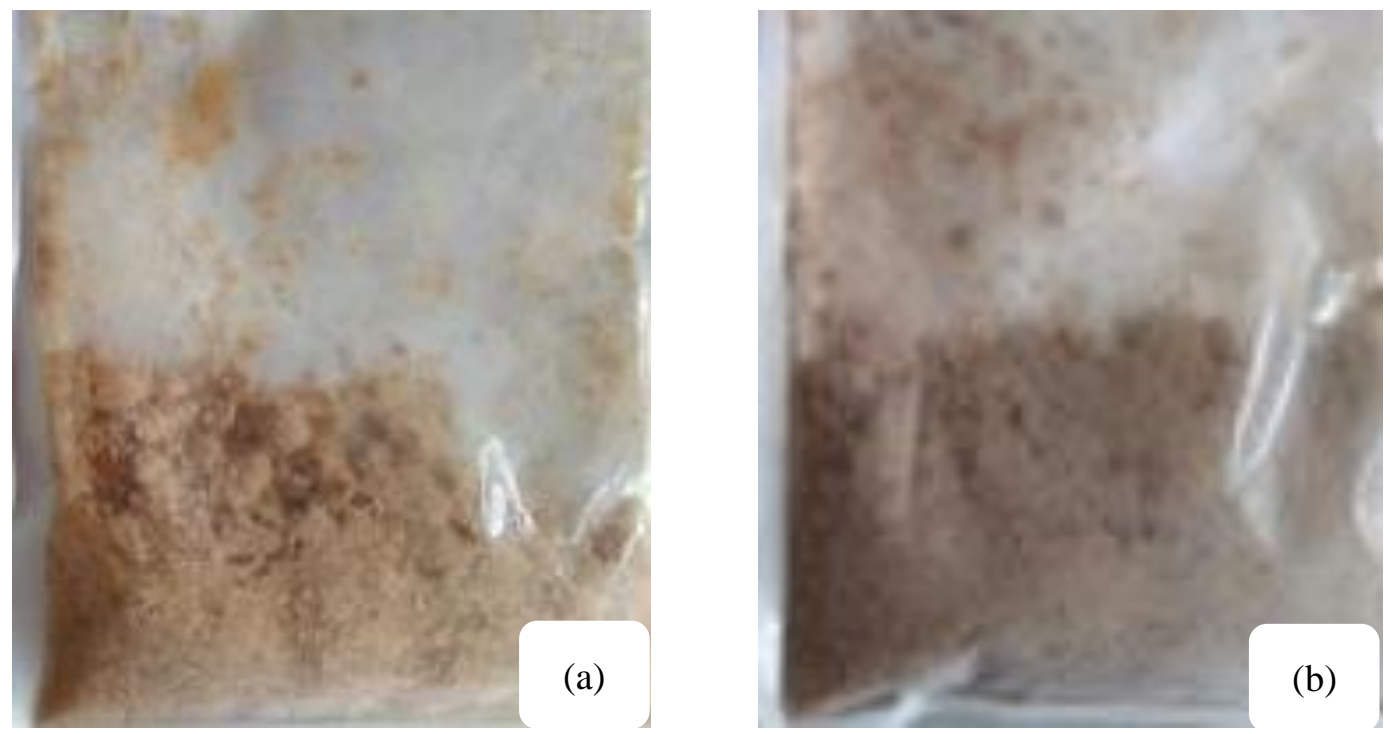

Figure3Appearance of (a) peanut flour and (b) black oncom flour

Figure 3 showed that the black oncom flour had a brown color with a smooth texture, while the peanut flour had a rather creamy brown color, with a slightly rough texture and oily moist. The production process of peanuts into flour was rather difficult because of their high fat content, in which the process of fining or grinding peanuts was too long to produce a paste and it was difficult in the sieving process. This made the yield of peanut flour was lower than that of black oncom flour. Another physical characteristic of flour was the $\mathrm{pH}$ value. Based on Table 1, the $\mathrm{pH}$ values of peanut flour and black oncom flour were not significantly different. This showed that the fermentation process in producing black oncom flour did not significantly change the $\mathrm{pH}$ value of peanuts, in which this measurement results is close to([25]reporting the $\mathrm{pH}$ value of tempeh flour at6.80. According to physical characteristics, especially in black oncom flour has good bulk density and water absorption that same with legume flour [26], so it has a good potential to be developed into food products

\subsection{Black Oncom Flour Nutritional Characteristics}

The nutritional characteristics of black oncom flour were presented in Table 2. The results of the independent t-test analysis showed that the water content of black oncom flour was significantly different from the water content of peanut flour, in which the water content of black oncom flour was higher than peanut flour. This can occur due to an increasing of water content in the fermentation process of black oncom. The treatment resulting high water subtances within the flour. The water content of the flour of this study same with cashew nut flour [27]. Beside that, the water content still fulfilled the flour water content standard of SNI (Indonesian National Standard) with a maximum limit of water content at $5 \%$.

Table 2Nutritional contents of peanut flour and black oncom flour (\%wet basis)

\begin{tabular}{|l|c|c|}
\hline Parameters & Peanut flour & Black oncom flour \\
\hline Water content (\%) & $3.16 \pm 0.19^{\mathrm{a}}$ & $4.82 \pm 0.23^{\mathrm{b}}$ \\
\hline Ash content $(\%)$ & $2.32 \pm 0.03^{\mathrm{a}}$ & $2.65 \pm 0.06^{\mathrm{b}}$ \\
\hline Protein content $(\%)$ & $28.62 \pm 4.35^{\mathrm{a}}$ & $43.96 \pm 0.17^{\mathrm{b}}$ \\
\hline Fat content $(\%)$ & $47.04 \pm 0.98^{\mathrm{a}}$ & $33.74 \pm 3.48^{\mathrm{a}}$ \\
\hline Carbohydrate content $(\%)$ & $13.85 \pm 4.05^{\mathrm{a}}$ & $18.86 \pm 5.19^{\mathrm{a}}$ \\
\hline
\end{tabular}

${ }^{a, b}$ means that in one line with different superscript lowercase letters, it was significantly different $(p<0.05)$

The water content of black oncom flour in this study was the same as [16] which was $3.16 \%$ and lower than the results of the studies [15] with values of $10 \%$. Black oncom flour also achieved a higher ash content than peanut flour. The high ash content indicatedhigherinorganic content in these products. High ash content was likely to occur due to the effect of fermentation which was able to reduce antinutrients thereby increasing dissolved mineral contents[28]. The content wassimilar to the results of [16], but it was lower than [15]. 
Similarly, the protein content of black oncom flour showed a significantly higher content (p <0.05) than peanut flour. The high protein content of black oncom flour occurred because of the fermentation process of carbon source materials such as carbohydrates through the Krebs cycle [29]. In addition, the formation of proteins can also occur from a high breakdown process that triggers the process of protein synthesis [28]. The protein content of black oncom flour was higher than the protein content of previous research results [16];[15] and same with tempeh flour that containing $44.85 \%$ [25].

Meanwhile, the fat and carbohydrate contents of peanut flour and black oncom flour werenot significantly different ( $p>0.05$ ), although the fat and carbohydratecontents of black oncom flour tended to be lower. Fat content of raw materials in the production of black oncom was removed.However, during the fermentation process, there wasan accumulation of lipids, so that the fat content of peanut flour and black oncom flour did not show a significant difference. Black oncom flour hada fat content in accordance with the results of [16] and was higher than the results of [25] with fat contents of $34.06 \%$ and $16.45 \%$, respectively. In addition, the carbohydrate content of black oncom flour in this study wasin understanding with the investigate comes about of[16].Refers to the nutritional contents, black oncom flour have high ash and protein content that offer complement ingredient in food product development such as biscuits[13]

\section{CONCLUSION}

Black oncom flour has a good potential to be developed into food products based on the analysis of physical characteristics and nutritional contents. This was revealed from its physical characteristics in the form of low bulk density, high water absorption capacity and no different $\mathrm{pH}$ value. As for the nutritional contents, black oncom flour showed high protein content which can be used as a source of protein supplementation through the development products. This research still has limitations, in which the production process of peanut flour still requires a good developed method to produce a high flour yield without forming a paste. In addition, further analysis of other nutritional content characteristics of peanut flour and black oncom flour, especially micro nutrients, is needed.

\section{ACKNOWLEDGMENT}

The authors thanks to the Ministry of Research and Technology for providing
PMDSU Program (Scholarship Programs Leading to Doctoral for Distinguished Bachelors) as study scholarship (Batch 3) and research funding (2018, 2019 and 2021).

\section{REFERENCES}

[1]O.T. Toomer, 'Nutritional chemistry of the peanut (Arachis hypogaea )',Crit". Rev .Food Sci.Nutr.,vol 58, no.17, pp.30423053, 2017.

[2]S.S. Arya, A.R. Salve, and S. Chauhan. 'Peanuts as functional food: a review",J. Food Sci.Technol.,vol 53, no. 1,pp.31-41, 2016, doi: 10.1007/s13197-015-2007-9.

[3]E.A. Bhat, N. Sajjad, I. Manzoor, and A. Rasool. 'Bioactive compounds in peanuts and banana". Biochem.Anal. Biochem.,vol. 2,pp. $1-4,2019$.

[4]R.Bonku, J. Yu. 'Health aspects of peanuts as an outcome of its chemical composition'. Food Sci. Hum. Wellness, vol. 9, no.1, pp. 21-30, 2020, doi:10.1016/j.fshw.2019.12.005.

[5]A. Rohimah, B. Setiawan, K. Roosita, E Palupi. 'The Amino Acid and Mineral Content of Black Oncom Processedwith Fermentation Modifications ",J. Gizi Pangan,vol. 6, Supp 1,2021 .

[6]M. Mao, et al.,. 'Effect of solid state fermentation by Enterococcus faecalis M2 on antioxidant and nutritional properties of wheat bran',J.Cereal Sci.,vol.94, 2020,doi: 10.1016/j.jcs.2020.102997.

[7]Z.M. Wang, Z.M. Lu, J.S. Shi, and Z.H.Xu.'Exploring flavour-producing core microbiota in multispecies solid-state fermentation of traditional Chinese vinegar',Sci". Rep.,vol. 6, pp. 1-10, 2016,doi: 10.1038/srep26818.

[8]Q. Xing, et al., 'Enhanced nutritional value of chickpea protein concentrate by dry separation and solid state fermentation",Innov.Food Sci. Emerg.Technol.,vol. 59, pp.102-269, 2020, doi: 10.1016/j.ifset.2019.102269.

[9]P. Kumbhare, "Analysis of nutritive value of peanut press cake, fermented by N.sitophila NCIM 899 and $R$. oligosporus NCIM 1215',Int. J. Res. Biosci. Agric. Technol., vol.2, no. 2, pp. 273-280, 2014.

[10]X. Yang et al.,'Enhancement of Nutritional and antioxidant properties of peanut meal by bio-modification with Bacillus licheniformis",Appl.Biochem.Biotechnol.,vo 1.180, no. 6, pp.1227-1242, 2016, doi: $10.1007 / \mathrm{s} 12010-016-2163-\mathrm{z}$. 
[11]D. Liu, S. Tang, Y. Shi, S. Yu, and H. Wu, "Comparison of the amino acid and protein content between peanut meal and fermented peanut meal',Adv. Mater. Res., vol. 344, pp.1042-1048, 2012, doi: 10.4028/www.scientific.net/AMR.343344.1042 .

[12]P.K. Sadh, P. Chawla, and J.S. Duhan. 'Fermentation approach on phenolic, antioxidantsand functional properties of peanut press cake',Food Bioscience,vol.22,pp.113-120， 2018， doi: 10.1016/j.fbio.2018.01.011

[13]B. Setiawan et al., 'Physical-sensory characteristics and nutritional contents of black oncom and peanut ingredients-based biscuits as an elderly supplementary food",AIMS Agric. Food,vol.5, no. 4, pp. 868-8812020, 2020, doi: 10.3934/agrfood..4.868.

[14]A. Rohimah,'Pengembangan produk biskuit tempe kacang tanah sebagai pangan yang berpotensi mengatasi balita gizi kurang','IPB University, 2016.

[15]D.A. Sudarta,'Pengembangan Cookies dari Tepung Labu Kuning, Tepung Biji Labu Kuning, Tepung Beras, dan Tepung Oncom Hitam yang Mengandung Omega 3', IPB University, 2018

[16]R. Novia. 'Pengembangan Produk Bronies dengan Substitusi Tepung oncom Hitam dan Sorgum untuk Balita Gizi Kurang', IPB University, 2018

[17]A.C.F. Bavia et al,.'"Chemical composition of tempeh from soybean cultivars specially developed for human consumption",Ciência e Tecnol. Aliment, vol. 32, no.3,pp. 613-620, 2012, doi: 10.1590/S010120612012005000085

[18]R. Singh, andR. Arivuchudar. 'Formulation and evaluation of peanut flour incorporated cookies",Int.J.Food Sci. Nutr., vol.3, no. 5, pp.56-59, 2018.

[19]O.A.A. Adouko, S. Traoré, E.A. Agbo, and B. Kouakou,'Functional Properties and in vitro Digestibility of Cashew Nut Flour',J. Food Nutr. Res.,vol. 4, no.5, pp. 282-288, 2016, doi: 10.12691/jfnr-4-5-3

[20]AOAC, 'Official Methods of Analysis of AOAC", International.18th Edition,2005.

[21]R. Fadilla. 'Perbandingan sifat fisikokimia isolat protein tempe dari kedelai kecambah dan non kecambah", IPB University, 2018.
[22]J.C. Ibeabuchi et al., "Comparative study on the proximate composition, functional and sensory properties of three varieties of beans Phaseolus lunatus, Phaseolus vulgaris and Vigna umbellata",Int.J. Adv. Eng.Technol. Manag. Appl. Sci.,vol. 5, no. 1, pp. 1-23, 2017.

[23]H. Kalaydzhiev, P. Ivanova, C.L.M. Silva, and V.I. Chalova,'Functional Properties of Protein Isolate and Acid Soluble ProteinRich IngredientCo-Produced from EthanolTreated Industrial Rapeseed Meal',Pol. J. Food Nutr. Sci.,vol. 69, no.2, pp.129-136, 2019, doi: 10.31883/pjfns-2019-0007.

[24]A.P. Kempka, T.C. Honaiser, E. Fagundes, and R.C. Prestes. 'Functional properties of soy protein isolate of crude and enzymatically hydrolysed at different times",Int. Food Res. J.,vol. 21, no. 6, pp.2229-2236, 2014.

[25]M.E. Omosebi, and E.T. Otunola,'Preliminary studies on tempeh flour produced from three different Rhizopus species",IJBFS, vol. 1, no. 5, pp. 90-96, 2013.

[26]Y.F. Cheng, and R. Bhat,'Functional, physicochemical and sensory properties of novel cookies produced by utilizing underutilized jering (Pithecellobium jiringa Jack.) legume flour'Food Biosci".,vol. 14 pp. 54-61.2016. doi: 10.1016/j.fbio.2016.03.002.

[27]B.C. Gadani, L. Miléski, L.S. Peixoto, and J.dS. Agostini. 'Physical and chemical characteristics of cashew nut flour stored and packaged with different packages',Food Sci". Technol (Campinas), vol. 37 no. 4,pp. 657-662, 2017,doi: 10.1590/1678457X.27516.

[28]S.G Nkhata, E. Ayua, and E. H.Kamau, "Fermentation and germination improve nutritional value of cereals and legumes through activation of endogenous enzymes',Food Sci".Nutr., vol. 6 no. 8,pp. 2446-2458.2018,doi: 10.1002/fsn3.846.

[29] M. Athenakia et al., 'Comparison between different D-Dimer cutoff values to assess the individual risk of recurrent venous thromboembolism: analysis of results obtained in the DULCIS study", Int. J. Lab. Hematol.vol. 38 no. 1, pp. 42-49.2016,doi: 10.1111/jam. 13633 